\title{
Pendidikan Teknologi di Sekolah Inklusi
}

\author{
Indah Mayangsari1; Unik Hanifah Salsabila²; Tari³; Irva Rani Zulaikha4; \\ Fisca Aprita Dewi ${ }^{5}$ \\ 1,3Universitas Ahmad Dahlan, Yogyakarta \\ ${ }^{2}$ Universitas Ahmad Dahlan, Yogyakarta \\ Contributor Email: indah1800031214@webmail.uad.ac.id ${ }^{1}$ \\ unik.salsabila@pai.uad.ac.id ${ }^{2}$ tari1800031138@webmail.uad.ac.id ${ }^{3}$ \\ irva1800031180@webmail.uad.ac.id ${ }^{4}$ fisca1800031208@webmail.uad.ac.id 5
}

\begin{abstract}
An inclusive school where a school allocates all children without exception to one room regardless of differences in physical, intellectual, social, emotional and other conditional. This includes children with disabilities, children who are lazy to learn, children who are not gifted, street children, who are in the lower class. Inclusive education technology provides a very wide open and friendly space in learning, the inclusive education system always prioritizes mutual respect for differences. Therefore the inclusive educational technology system aims to remove barriers and solve problems and support the implementation of inclusive education for children with special needs. Several adaptive technologies are very important, namely NVDA (Non-Visual Desktop Access), JAWS (Job Access With Speech), I-Chat (I Can hear and talk). This service intends not to differentiate between children from one another, regardless of their background, economy and culture, so that they can develop learning like children in general. improving the success of the goals of inclusive school education.
\end{abstract}

Keywords: Education, Inclusion, Technology.

\begin{abstract}
Abstrak
Sekolah inklusif adalah sekolah yang mengalokasikan semua anak tanpa terkecuali dalam satu ruangan tidak menghiraukan perbedaan kondisi fisik, intelektual, social, emosional dan kondisi lainya. Hal ini termasuk bagi anak yang cacat/berkelainan, anak yang malas belajar, anakyang tidak berbakat, anak jalanan dan anak yang berada di golongan bawah. Teknologi Pendidikan inklusi memberikan ruang yang sangat luas, terbuka, serta ramah tamah dalam pembelajaran, system pendidikan inklusi selalu mengutamakan perilaku saling menghargai atas perbedaan. Karena itu system teknologi pendidikan inklusi bertujuan untuk menghilangkan hambatanhambatan dan memecahkan masalah serta mendukung pelaksanaan Pendidikan inklusi terhadap anak yang berkebutuhan khusus. Terdapat beberapa teknologi adaptifyang berperan penting yaitu, NVDA (Akses Desktop NonVisual), JAWS (Akses Pekerjaan dengan Ucapan), I-Chat (saya dapat mendengar dan berbicara). Layanan ini bermaksud untuk tidak membeda-bedakan anak yang satu dangan yang lainya, tidak memandang latar belakangnya, ekonomi dan budaya, sehingga mereka bisa berkembang, belajar seperti anak-anak pada umumnya. Salah satu yang menjadi hal yang terpenting dari suksenya sebuah pendidikan inklusi yakni meningkatkannya kualitas dari tenaga pendidik.
\end{abstract}

Kata Kunci: Pendidikan, Teknologi, dan Inklusi. 


\section{A. Pendahuluan}

Aset bangsa yang sangat penting adalah seorang anak yang diberikan perhatian dan juga pendidikan yang baik dalam semua aspek dengan tujuan untuk menjadi manusia berkarakter yang berkualitas di kemudian hari. Mengembangkan kemampuan dan membeentuk watak serta peradaban bangsa yang bermartabar dalam rangka mencerdaskan kehidupan bangasa hal ini telah tertera dalam Undang-undang no 20 tahun 2003. Pendidikan merupakan hak dasar bagi semua warga di Indonesia sekalipun itu anak berkebutuhan khusus. Perbedaan tidak perlu menjadi perdebatan melainkan perbedaan menjadi hal yang perlu di unggulkan. Setiap anak terlahir membawa keunikan masing-masing. Pemerintah sangat berperan penting dalam menyelenggarakan pendidikan yang merata dan juga dalam pengembangan pendidikan agar mutu pendidikan indonesia semakin baik (indah \& binahayati, 2015).

Penyelenggaraan pendidikan untuk anak berkebutuhan khusus pemerintah telah menyediakan fasilitas pendidikan yang khusus untuk anak berkebutuhan khusus disebut dengan SLB (Sekolah Luar Biasa). Namun, hal ini membuat menjadi sebuah jarak yang dapat memisahkan antara anak berkebutuhan khusus dengan anak normal pada umum nya, hal tersebut menjadi penghambat dalah berinteraksi di antara mereka (indah \& binahayati, 2015). Hal tersebut akan membuat anak berkebutuhan khusus merasa tersingkirkan ketika berinterasi dengan masyarakat. Anak berkebutuhan khusus akan berspekulasi bahwa mereka bukan bagian dari kehidupan masyarakat. Anak berkebutuhan khusus juga mempunyai hak dan kewajiban serta perlu meyesuaikan dengan lingkungannya jadi wajar saja jika meraka menginginkan agar dapat berpartisipasi di lingkungan mereka.

Sekolah inklusi merupakan salah satu lembaga pendidikan untuk semua anak tanpa diskriminasi dimana disekolah ini anak-anak dapat belajar bersama tanpa ada perbedaan. Di sekolah inklusi semua peserta didik mendapatkan hak dan kewajiban yang sama tanpa ada perlakuan khusus (indah \& binahayati, 2015). Dalam proses belajar mengajar teknologi pembelajaran sangat berperan penting dalam proses pembelajaran, dengan 
itu dapat menjadi sebuah pembelajaran dalam pendidikan inklusi yang mampu memecahkan masalah.

Alat bantu atau media merupakan komponen yang penting dalam sebuah pendidikan dalam membantu kebutuhan peserta didik (ariyanto, 2017). Dalam lembaga pendidikan inklusif teknologi adaptif dapat membantu anak berkebutuhan khusus dimana mereka dilatih menggunakan media teknologi seperti peserta didik yang lainnya, oleh karena itu teknologi adaptif dapat membantu mereka dalam proses pembelajaran. Agar tercapainya proses pembelajaran maka perlu di perhatikan target mengenai para peserta didik sehingga dapat memberikan evaluasi kedepannya agar dapat mengetahui kekurangan apa saja dalam proses pembelajaran di kelas maupun di luar kelas.

\section{B. Metode}

Penelitian merupakan penelitian studi literatur menggunakan beberapa jurnal mengenai pendidikan teknologi di sekolah inklusi. Hasil dari berbagai telaah literatur akan digunakan untuk mengidentifikasi bagaimana pendidikan teknologi di sekolah inklusi terlaksanakan.

\section{Hasil dan Pembahasan}

Penggunaan teknologi di sekolah inklusif merupakan tantangan bagi seorang guru agar lebih banyak menggunakan strategi dan metode pembelajaran di mana agar dapat memahamkan kepada peserta didiknya. Mendidik di sekolah inkusif merupakan tantangan sebagai seorang guru agar terus bersabar dan mampu membuat anak-anak ABK merasa nyaman dan juga merasa bahwa mereka mempunyai hak yang sama seperti anak normal biasanya. Dalam sebuah proses belajar strategi dan juga metode pembelajaran menjadi hal yang sangat penting apalagi untuk guru yang mengajar di sekolah inkusif. Media pembelajaran juga bagian penting dan proses pembelajaran karena hal itu akan membantu keefektivan dalam menyampaikan materi oleh karena itu perlu mencari media pembelajaran yang menarik dan membuat peserta didik memahami materi tersebut. 
Pemeritah indonesia telah memberikan jaminan kepada peserta didik anak berkebutuhan khusus untuk memperoleh pendidikan yang bermutu. Hal tersebut sesuai dengan amanat dengan Undang-undang Dasar 1945 pasal 31 ayat 1 dan undang-undang Nomor 20 tahun 2003 tentang Sistem Pendidikan Nasional. Oleh karena itu tidak perlu menjadi perdebatan adanya perbedaan melainkan menjadikannya sebagai keunggulan. Maka dari itu untuk mewujudkan undang-undang tersebut diperlukan sistem pendidikan yang menjalankan undang-undang tersebut yaitu dengan model pendidikan inklusi.

Kompenen yang penting di dalam sekolah inklusi yakni adanya alat bantu atau media yang di butuhkan peserta didik. Alat dan media pembelajaran berbeda dengan yang biasa digunakan oleh peserta didik pada umumnya. Salah satu teknologi asistif yang berperan penting dalam proses belajar yaitu komputer. Bagian dan juga perangkat yang berperan penting bagi pendidikan inklusif adalah komputer dan juga jaringan komputer. Dalam konteks pendidikan inklusi anak berkebutuhan khusus sudah seharusnya dapat mengggunakan media teknologi seperti peserta didik pada umumnya. Sehingga dapat membantu anak berkebutuhan khusus untuk dalam proses belajar. Dari banyaknya teknologi adaptif yang terpenting adalah yang dapat mengakseskan jaringa ke komputer dan teknologi informasi. Terdapat beberapa teknologi adaptif yang sangat penting yaitu NVDA (Non visual Desktop Access), JAWS (Job Access With Speech), I-chat (I can hear and talk) (ariyanto, 2017).

\section{1) NVDA (non visual desktop access)}

Merupakan teknologi berupa pembaca layar (screen reader) tidak berbayar yang dapat mempermudah anak berkebutuhan khusus seperti tunanetra dan anak yang memiliki gangguan pengelihatan untuk menggunakan komputer. Aplikasi tersebut memiliki cara kerja dengan membaca teks pada layar berupa suara yang terdapat di dalam komputer dan pembaca dapat memindahkan kursor di bagian yang terdapat teks, dengan adanya tanda panah di keyboard pembaca bisa membaca apa yang akan dibaca. Bagi tunanetra dan anak yang memiliki gangguan pengelihatan dapat 
memberikan instruksi kepada komputer dan menjawab pesan cukup dengan memaksimalkannya dalam menghafal tempat dan fungsi keyboard komputer. Keyboard ini di input dengan proses memasukkan peralatan dengan cara mengaktifkan melalui tombol yang tersedia di keyboard, jadi dalam menggunakan komputer bicara ini tunanetra dan anak yang memiliki gangguan penglihatan dapat memilih perintah yang terdapat di menu yang bisa di akses melalui tombol yang terdapat di keyboard atau menekan tombol shortcut (Apriliana, 2015)

\section{2) JAWS (Job Access With Speech)}

Program Jaws merupakan hardware dan software yang dapat mengeluarkan suara bacaan, baik itu tulisan cetak maupun barille. Teknologi ini berkembang sangat pesat dan dapat memberikan kesempatan dan pembelajaran yang baru untuk peserta didik yang terhambat dalam penglihatannya (j, 2012). Program jaws dapat digunakan oleh penyandang tunanetra dalam proses pendidikan sebagai media pembelajaran. Dengan terciptanya program tersebut akan sangat membantu proses belajar bagi penyandang tunanetra sehingga mereka tidak akan mengalami ketertinggalan dalam memahami materi pembelajaran dan tugas-tugas yang diberikan oleh guru atau pendidik. Di dalam program ini mereka bisa memutar file yang berisi materi pembelajaran sehingga mereka dapat membuat tugas secara mandiri dan juga tugas tersebut dapat dicetak baik dalam bentuk tulisan latin maupun media cetak braile (meri \& zulvanti, 2018).

\section{3) I-chat (I can hear and talk)}

Aplikasi i-CHAT (I Can Hear and Talk) adalah aplikasi pembelajaran dengan menggunakan bahasa Isyarat berbasis komputer yang dirancang untuk Anak yang mengalami kurangnya dalam pendengaran atau tunanetra yang dikemas dalam bentuk multimedia (Paula, Indriyani, \& Kadek, 2020). Aplikasi I-chat telah di sosialisasikan kurang lebih 122 SLB-B di Indonesia, IChat ini merupakan Program CSR (Corporate Social Responsibility) dari PT. Telekomunikasi Indonesia, Tbk. Hingga saat ini, aplikasi i-CHAT memuat 7000 
kata dalam bentuk konten vidio dan pengucapan. Aplikasi ini dapat bermanfaat bagi komunitas berkebutuhan khusus dalam pendengaran serta orang tua, guru, dan kerabat mereka. Aplikasi i-CHAT tersedia untuk Bahasa Isyarat Indonesia \& Malaysia (Melayu) (paula, Indriyani, \& Kadek, 2020) . Aplikasi ini mengarahkan pengguna untuk belajar Bahasa Isyarat Indonesia \& Malaysia dan bagaimana mengatur kalimat afirmatif (Andreas \& Bilpen, 2016).

\section{Sistem Layanan Pendidikan Inklusi Di Indonesia}

Berbagai dunia berupaya untuk memberikan pelayanan pendidikan untuk anak berkebutuhan khusus hal ini menjadi sebuah keprihatinan negara karena masih banyak anak-anak berkebutuhan khusus yang tidak mendapatkan pelayanan pendidikan. Maka dari itu muncullah pendidikan inklusif sebagai hak asasi manusia (deklarasi International mengenai HAM 1948 dan konvensi International tentang Hak Anak, 1989). Pemerintah indonesia telah berusaha untuk memfasilitasi layanan pendidikan bagi anak berkebutuhan khusus yakni sekolah luar biasa (SLB) yang sudah ada di beberapa wilayah di Indonesia, namun hal ini menjadi sebuah tembok pemisah bagi anak berkebutuhan khusus dengan anak normal pada umumnya. Anak berkebutuhan khusus akan merasa terasingkan dalam proses interaksi dengan masyarakat. Di dalam UU No 20 tahun 2003, pasal 5 dinyatakan bahwa "setiap warga negara mempunyai hak yang sama untuk mendapatkan pendidikan, dan sekalipun itu anak berkebutuhan khusus" dari sisni jelas bahwa sudah menjadi kewajiban pemerintah dalam memfasilitasi dan memberikan hak pendidikan kepada anak berkebutuhan khusus.

\section{Penerapan Teknologi Di sekolah Inklusi}

Teknologi di zaman sekarang sangat berperan penting dalam proses pembelajaran. Dalam hal ini guru sangat dituntut untuk bisa mengoperasikan teknologi agar mampu melaksankan proses belajar berbasis IT. Penggunaan teknologi di sekolah inklusif merupakan tantangan bagi seorang guru agar 
lebih banyak menggunakan strategi dan metode pembelajaran dimana agar dapat memahamkan kepada peserta didiknya.

Dalam menerapkan teknologi di sekolah inklusi maka diperlukan pengintegrasian sebuah alat pembelajaran yang sesuai kondisi pembelajaran bagi anak berkebutuhan khusus dengan anak normal pada umumnya. Dalam penggunaan teknologi merupakan hal yang efektif dalam membantu anak berkebuhuan khusus untuk bisa memahami sebuah materi pembelajaran.

\section{Tujuan Menggunakan Teknologi di Pembelajaran sekolah inklusi}

Anak berkebutuhan khusus dalam proses belajar mengalami sedikit kesulitan, contoh, siswa yang memiliki ganggguan pendengaran yang mana mereka bergantung kepada gerakan bibir seseorang untung bisa mengetahui apa yang mereka katakan (M, 2012). Oleh karena itu perlu mengenalkan teknologi asistif yang dapat membantu peserta didik, untuk itu pengajar agar dapat memanfaatkan aktivitas teknologi yang membantu peserta didik. Sangat berperan penting teknologi sebagai media pembelajaran dalam membantu anak berkebutuhan khusus yang telah di atur sebaik mungkin agar bisa digunakan untuk anak berkebutuhan khusus.

\section{Kesimpulan}

Penggunaan teknologi di sekolah inklusif merupakan tantangan bagi seorang guru agar lebih banyak menggunakan strategi dan metode pembelajaran agar dapat memahamkan kepada peserta didiknya. Penggunaan teknologi di sekolah inklusif merupakan tantangan bagi seorang guru agar lebih banyak menggunakan strategi dan metode pembelajaran dimana agar dapat memahamkan kepada peserta didiknya. Mendidik di sekolah inkusif merupakan tantangan sebagai seorang guru agar terus bersabar dan mampu membuat anak-anak ABK merasa nyaman dan juga merasa bahwa mereka mempunyai hak yang sama seperti anak normal biasanya. Keterbatasan karena hambatan tertantu yang dialamai anak berkebutuhan khusus tentu membutuhkan alat bantu teknologi adaptif, teknologi yang bisa memberikan akses computer dan teknologi informasi. Terdapat beberapa teknologi adaptif 
yang sangat penting yaitu, NVDA (Akses Desktop NonVisual), JAWS (Akses

Pekerjaan dengan Ucapan), I-Chat (saya dapat mendengar dan berbicara).

\section{DAFTAR PUSTAKA}

Andreas, W. Y., \& Bilpen, N. (2016). I Can Hear and Talk (I-Chat) as ASEAN Sign Language Computer Application For Hearing Impaired. International Journal of Innovative Research In Technology \& Science (JIRTS), 37.

Apriliana, N. (2015, November 10). Pemanfaatan Komputer bicara dalam Memenuhi Kebutuhan Informasi Tunanetra di Yayasan Mitra Netra. Dipetik November 18, 2020, dari Institutional Respository UIN Syarif Hidayatullah Jakarta: http://repository.uinjkt.ac.id/dspace/handle/123456789/28847

Ariyanto, d. (2017). peran teknlogi pembelajaran dalam mendukung implementasi pendidikan inklusi. jember: international conference on special education in southeast asia region. https://scholar.google.co.id/scholar?q=related:3q5ZBa iWG4J:scholar .google.com/\&scioq=tujuan+teknologi+pendidikan+di+sekolah+inklus $\underline{\mathrm{i} \& \mathrm{hl}=\mathrm{id} \& \text { as } \mathrm{sdt}=0,5}$

Indah, p. d., \& binahayati, r. (2015). pelaksanaan sekolah inklusi di indonesia. prosiding penelitian \& pengabdian kepada masyarakat, 223. https://doi.org/10.24198/jppm.v2i2.13530

J, d. s. (2012). sekolah inklusif. bandung: nuansa.

M, s. (2012). pengembangan teknologi asistif bagi anak berkebutuhan khusus dalam seting pendidikan inklusif. bandung: universitas pendidikan indonesia.

Meri, s., \& zulvanti, n. (2018). pelayanan pendiidkan inklusi bagi tunanetra (Di IAIN studi kasus Imam Bonjol Padang). Al-Irsyad: Jurnal Bimbingan dan Konseling Islam 47. https://www.ejournal.uinib.ac.id/jurnal/index.php/alirsyad/article/v iew $/ 124$

Paula, d., Indriyani, \& Kadek, V. V. (2020). Pengenalan Aplikasi Pembelajaran Bahasa Isyarat I-Chat untuk Anak Berkebutuhan Khusus di Panti Asuhan Semara Putra Klungkung. jurnal WIDYABHAKTI Ilmiah Populer, 2.

http://widyabhakti.stikombali.ac.id/index.php/widyabhakti/article/v iew $/ 190$ 